\title{
The Influence Of Participation Leadership, Organizational Culture, Innovation To Organizational Capability And Cooperative Performance In The Province Of South Kalimantan
}

\author{
Abdul Kadir Audah \\ Doctoral Student of Ecomic and business \\ University of 17 August 1945 Surabaya \\ Ujianto \\ University of 17 August 1945 Surabaya \\ Amiartuti Kusmaningtyas \\ University of 17 August 1945 Surabaya
}

\begin{abstract}
This study aims to prove and analyze the influence of participation leadership, organizational culture, innovation to organizational capabilities and performance of cooperatives in the province of South Kalimantan. The population in this study were all Cooperatives that had implemented RAT in South Kalimantan Province as many as 660 Cooperatives, as many as $\mathbf{2 4 9}$ Cooperatives in the sample. The data used in this study are primary data sourced from the questionnaire. Data analysis and hypothesis testing in this study using the Structural Equation Model (SEM). The results of the hypothesis testing prove that participation leadership, organizational culture and innovation have a significant effect on organizational capacity in cooperatives in South Kalimantan. Participatory leadership has a significant effect on the performance of cooperatives in South Kalimantan. Organizational culture and innovation have no significant effect on the performance of cooperatives in cooperatives in South Kalimantan. Organizational ability has a significant effect on the performance of cooperatives in South Kalimantan.
\end{abstract}

Keywords: Participation leadership, Organizational Culture, Innovation, Organizational Ability, Cooperative Performance

\section{INTRODUCTION}

In the economic field, the role of cooperatives is felt in national development because cooperatives play many roles in helping to increase income and prosperity, especially members and the community in general, help improve business capacity, both individuals and communities, help the government in providing employment, help improve living standards society, organizing democratic economic life, assisting the development and development of economic potential of members in particular and the general public and strengthening the people's economy as a basis for the strength and resilience of the national economy.

Based on collected data, the number of cooperatives in Indonesia until the end of 2017 touched 213,146 units. But based on data collection, the active cooperative is only 151,284 units. This amount is obtained through cooperative data updating carried out with the Online Database System.

Based on 2017 data, the number of Cooperatives and MSMEs in South Kalimantan from the South Kalimantan Provincial Cooperative, Small and Medium Enterprises Office shows that there are 51,189 micro and small business actors in South Kalimantan, more than micro, small 
and medium enterprises (MSMEs). in it included 2,461 cooperatives, all of which were able to absorb 102,378 more workers.

\section{LITERATURE REVIEW AND HYPOTESIS}

Leadership Participation is an ability to carry out or do a job or task based on skills and knowledge and is supported by the work attitude demanded by the work which is measured by the influence of idealism, Inspirational motivation and Individual consideration. Organizational Culture is the ability to work together between each agency that is mutually beneficial. (Denison and Mirsha 2012), measured through Engagement, Consistency and Adaptation. Innovation is a contribution as well as utilizing Cooperatives in the province of South Kalimantan as measured by, Relative Advantage, Compatibility and Observable Capabilities.

Organizational Ability (Ulrich \& Smallwood, 2004) that is adaptation to customer needs in contributing to and utilizing Cooperatives in the province of South Kalimantan as measured by Coordination, Expertise and Proactivity.

Cooperative Performance is a reflection in the form of a financial perspective and the perspective of internal cooperative business processes, members success which in this case is reflected in the form of member / consumer satisfaction / customer perspective, and customer loyalty, and development success which in this case is reflected by cooperative learning and growth perspectives both the number of members, the number of assets, and the amount of capital (Sudarmanto 2015), which is measured using financial perspective, customer perspective, internal business process perspective and growth and learning perspective.

Hanifah (2011: 7) Entrepreneurial orientation, organizational culture and business strategy jointly influence the performance of the company. Together with entrepreneurial orientation implemented effectively, the existing organizational culture is formed very strongly and the business strategy is truly considered and implemented, then together will improve company performance.

Hara (2013: 12) The Entrepreneurship and Organizational Culture Orientation simultaneously has a significant influence on Company Performance. This is based on the existence of a strong relationship between the variable Entrepreneurship Orientation and Organizational Culture with company performance. Partially the Entrepreneurship Orientation and Organizational Culture variables have a significant influence on Company Performance.

Wiklund and Shepherd (2005: 89) identify a positive relationship between entrepreneurial orientation and business performance. However, Frank et al .'s research (2010: 195) entrepreneurial orientation has a negative effect on business performance. Likewise, previous studies of Lumpkin and Dess (2001: 13) show a weak relationship between entrepreneurial orientation and company performance.

\section{RESEARCH METHODE}

The population in this study were all Cooperatives that had implemented RAT in South Kalimantan Province as many as 660 Cooperatives, as many as 249 Cooperatives in the sample. The data used in this study are primary data sourced from the questionnaire. Data analysis and hypothesis testing in this study using the Structural Equation Model (SEM). 


\section{ANALYSIS AND DISCUSSION}

The results of the calculation of the values of the goodness of fit indices produced by the Modification model indicate the model of goodness of fit.

Goodness of Fit Index Test Modification Results

\begin{tabular}{|c|c|c|c|}
\hline Criteria & $\begin{array}{c}\text { Model Test } \\
\text { Results }\end{array}$ & $\begin{array}{c}\text { Critical } \\
\text { Value }\end{array}$ & Information \\
\hline $\begin{array}{c}\text { Probability } \\
\mathrm{X}^{2} \text { Chi square }\end{array}$ & 0,000 & $\geq 0,05$ & Not Fit \\
\hline Cmin/DF & 1,536 & $\leq 2,00$ & Fit \\
\hline RMSEA & 0,046 & $\leq 0,08$ & Fit \\
\hline GFI & 0,920 & $\geq 0,90$ & Fit \\
\hline AGFI & 0,891 & $\geq 0,90$ & Marginal Fit \\
\hline TLI & 0,951 & $\geq 0,95$ & Fit \\
\hline CFI & 0,960 & $\geq 0,95$ & Fit \\
\hline
\end{tabular}

The calculation results show that the majority of the goodness of fit criteria have provided an index that is in accordance with the recommended (fit or marginal). While the chi-square statistic is still not fit (probability value is still less than 5\%), this is not a problem because according to Ferdinand (2002), the chi-square statistic is the most fundamental measuring tool, but in the sample above 200, statistics This chi-square becomes sensitive, so it must use other models of conformity measurement. Based on the theory, the sample in this study amounted to 249 (more than 200), so the use of chi-square for the model suitability criteria became biased and sensitive to the number of samples, so it was better to use other models of conformity measurement.

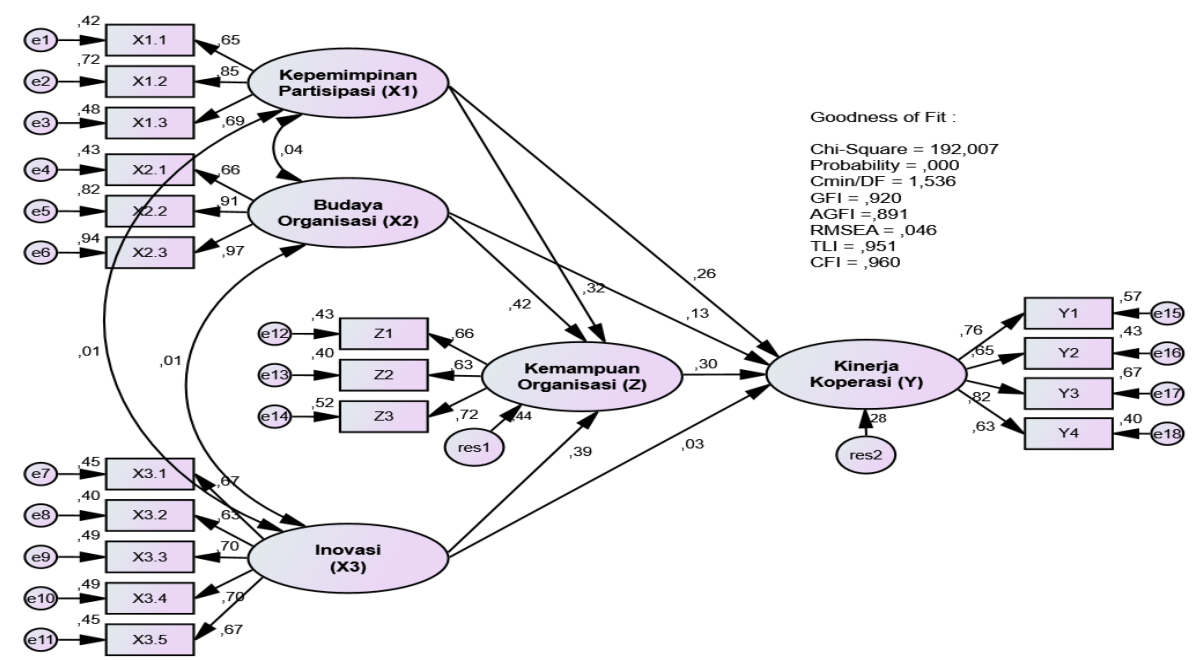

Image of Full Structural Model 
Audah, A. K., Ujianto., \& Kusmaningtyas, A. (2019). The Influence Of Participation Leadership, Organizational Culture, Innovation To Organizational Capability And Cooperative Performance In The Province Of South Kalimantan. Archives of Business Research, 7(3), 125-132.

Results of Standardized Regression Weight Analysis

\begin{tabular}{|c|c|c|c|c|c|c|c|}
\hline Hip. & \multicolumn{3}{|c|}{ Causality Relations } & $\begin{array}{c}\text { Std. } \\
\text { Estimate }\end{array}$ & C.R. & $\begin{array}{c}P \\
\text { value }\end{array}$ & Information \\
\hline $\mathrm{H}_{1}$ & $\begin{array}{l}\text { Leadership } \\
\text { Participation (X1) }\end{array}$ & & $\begin{array}{l}\text { Organizational } \\
\text { Ability (Z) }\end{array}$ & 0,325 & 4,141 & 0,000 & Sig \\
\hline $\mathrm{H}_{2}$ & $\begin{array}{l}\text { Organizational } \\
\text { culture (X2) }\end{array}$ & $\rightarrow$ & $\begin{array}{l}\text { Organizational } \\
\text { Ability (Z) }\end{array}$ & 0,418 & 5,060 & 0,000 & Sig \\
\hline $\mathrm{H}_{3}$ & Innovation (X3) & & $\begin{array}{l}\text { Organizational } \\
\text { Ability (Z) }\end{array}$ & 0,386 & 4,637 & 0,000 & Sig \\
\hline $\mathrm{H}_{4}$ & $\begin{array}{l}\text { Leadership } \\
\text { Participation (X1) }\end{array}$ & $\rightarrow$ & $\begin{array}{l}\text { Cooperative } \\
\text { Performance (Y) }\end{array}$ & 0,261 & 3,013 & 0,003 & Sig \\
\hline $\mathrm{H}_{5}$ & $\begin{array}{l}\text { Organizational } \\
\text { culture (X2) }\end{array}$ & & $\begin{array}{l}\text { Cooperative } \\
\text { Performance (Y) }\end{array}$ & 0,129 & 1,547 & 0,122 & Not Sig \\
\hline $\mathrm{H}_{6}$ & Innovation (X3) & $\rightarrow$ & $\begin{array}{l}\text { Cooperative } \\
\text { Performance (Y) }\end{array}$ & 0,030 & 0,339 & 0,735 & Not Sig \\
\hline $\mathrm{H}_{7}$ & $\begin{array}{l}\text { Organizational } \\
\text { Ability (Z) }\end{array}$ & $\rightarrow$ & $\begin{array}{l}\text { Cooperative } \\
\text { Performance (Y) }\end{array}$ & 0,305 & 2,562 & 0,010 & Sig \\
\hline
\end{tabular}

Analysis of the influence between variables can be explained by each hypothesis as follows:

\section{Effect of leadership participation on organizational capabilities}

The results of research and testing using SEM with the help of AMOS v.20 Software showed a significant effect of leadership participation on organizational capabilities in cooperatives in South Kalimantan. The parameter estimation effect of participation leadership on organizational ability shows significant results with a CR value greater than 1.96, and a significance value (p-value) smaller than $5 \%$, so the first hypothesis which states that participation leadership has a significant effect on organizational ability in cooperatives in South Kalimantan, it is acceptable. The results of this study are consistent with the results of the research of Idris (2011) that motivational and inspirational participation leadership brings management to become individuals who are able to run the cooperative well.

\section{Effect of organizational culture on organizational capabilities}

The results of research and testing using SEM with the help of AMOS v.20 Software showed a significant influence of organizational culture on organizational capabilities in cooperatives in South Kalimantan. The parameter estimation effect of organizational culture on organizational ability shows significant results with a CR value greater than 1.96, and a significance value (pvalue) smaller than $5 \%$, so the second hypothesis which states that organizational culture has a significant effect on organizational ability in cooperatives in South Kalimantan, it is acceptable. The results of this study are consistent with the results of the Inter-study and Komenaung (2003), Herminingsih (2011), Situmorang (2013), Purnama (2013), and Koesmono (2014) which also show that organizational culture has a significant effect on organizational ability.

\section{Effect of innovation on organizational capabilities}

The results of research and testing using SEM with the help of AMOS v.20 Software showed a significant effect of innovation on organizational capabilities in cooperatives in South Kalimantan. The parameter estimation effect of innovation on organizational capability shows significant results with a CR value greater than 1.96, and the significance value (p-value) is smaller than 5\%, so the third hypothesis states that innovation has a significant effect on organizational ability in cooperatives in South Kalimantan, acceptable. The results of this study are consistent with the results of the Antaradan study and Komenaung (2003), Prakoso (2005), Muafi (2009), Frank Potet al. (2012), Hafeezet al. (2012), as well as Kumalaningrum and 
Kusumawati (2013) which also shows that innovative organizations have better ability to run the organization.

\section{Effect of leadership participation on cooperative performance}

The results of research and testing using SEM with the help of AMOS v.20 Software showed a significant influence of leadership participation on the performance of cooperatives in South Kalimantan. The parameter estimation effect of participation leadership on cooperative performance shows significant results with a CR value greater than 1.96, and the significance value ( $\mathrm{p}$-value) is smaller than $5 \%$, so the fourth hypothesis which states that participation leadership has a significant effect on cooperative performance in South Kalimantan, acceptable. The results of this study are consistent with the results of research by Fathurrozi (2000), Antaradan and Komenaung (2003), Hasnawati (2004), Cho and Sansereau (2010), Zulfanetti (2011), Ghozali (2011), and Koesmono (2014) who also show participation leadership influences performance organization.

\section{Effect of organizational culture on cooperative performance}

The results of research and testing using SEM with the help of AMOS v.20 Software showed that there was no significant effect of organizational culture on the performance of cooperatives in South Kalimantan. The parameter estimation effect of organizational culture on cooperative performance shows insignificant results because the CR value is smaller than 1.96, and the significance value ( $p$-value) is greater than $5 \%$, so the fifth hypothesis states that organizational culture has a significant effect on performance cooperatives in South Kalimantan, cannot be accepted. The results of this study are not consistent with the results of the study of Herminingsih (2011), Situmorang (2013), and Purnama (2013) which show organizational culture influences the performance of cooperatives. The reason for the noninfluence of organizational culture on cooperative performance is due to the low consistency that is in the management of cooperative organizations, this consistency is the lowest indicator of organizational culture by the management. Lack of consistency in the implementation of RATs, irregular distribution of SHUs, and lack of relations and communication between the management and Dekopin and the Regional Cooperative Office. Lack of consistency fades member trust, which in turn can result in less encouraging cooperative performance. Another reason is the culture or habits of changing cooperative management that are too fast, so that the working period of some cooperative managers is still new, their experience in managing cooperatives is still low so that cooperative performance is not optimal.

\section{Effect of innovation on cooperative performance}

The results of research and testing using SEM with the help of AMOS v.20 Software showed that there was no significant effect of innovation on the performance of cooperatives in South Kalimantan. The parameter estimation effect of innovation on cooperative performance shows insignificant results because the CR value is smaller than 1.96, and the significance value (pvalue) is greater than $5 \%$, so the sixth hypothesis states that innovation has a significant effect on cooperative performance in South Kalimantan, cannot be accepted. The results of this study are not consistent with the results of the Inter-study and Komenaung (2003), Frank Potet al. (2012), and Hafeezet al. (2012) which shows innovation influences the performance of cooperatives. The reason for the non-influence of innovation on the performance of cooperatives is because innovations that appear less tested, the lack of a trial is an indicator of innovation that is considered the lowest by the management. The administrators still lacked the courage to try new innovative ideas for fear of failure, besides that the administrators were still reluctant to adopt advanced cooperative management. This lack of courage makes existing innovations futile, so that cooperative performance becomes stagnant or even decreases due to losing competition with other more innovative cooperatives. 


\section{Effect of organizational capabilities on cooperative performance}

The results of research and testing using SEM with the help of AMOS v.20 Software showed a significant influence on the ability of the organization on the performance of cooperatives in South Kalimantan. The parameter estimation effect of organizational ability on cooperative performance shows significant results with a CR value greater than 1.96 , and a significance value (p-value) smaller than $5 \%$, so the seventh hypothesis states that organizational ability has a significant effect on cooperative performance in South Kalimantan, acceptable. The results of this study are consistent with the results of the Inter-study and Komenaung (2003) which also show organizational capabilities influence the performance of cooperatives.

\section{SUMMARY}

Based on the formulation of the problem, the literature review, the results of the research and discussion can be concluded:

1. Participation leadership influences the ability of the organization, the better the leadership participation, the better the organizational capacity of cooperatives in South Kalimantan.

2. Organizational culture influences the ability of the organization, the stronger the organizational culture, the better the organizational capacity of cooperatives in South Kalimantan.

3. Innovation has an effect on the ability of the organization, the higher the innovation, the higher the organizational capacity of cooperatives in South Kalimantan.

4. The participation leadership affects the performance of cooperatives, the better the leadership participation, the better the performance of cooperatives in South Kalimantan.

5. Organizational culture has no effect on cooperative performance, the better participation leadership does not have a significant impact on improving cooperative performance in South Kalimantan.

6. Innovation also does not affect the performance of cooperatives, the higher the innovation does not have a significant impact on improving the performance of cooperatives in South Kalimantan.

7. Organizational capabilities affect the performance of cooperatives, the better the ability of the organization, the better the performance of cooperatives in South Kalimantan.

\section{LIMITATION}

The limitations of the results of this study, based on the results of the study after conducting testing and analysis of all existing data. It is realized that it has not been able to answer completely the relationship of the influence of variables of leadership participation, organizational culture, innovation, organizational ability, and cooperative performance. The limitations of this study are due to:

1. The theoretical basis that underlies the relationship between independent variables about the influence of leadership participation, organizational culture, and innovation on organizational capabilities and cooperative performance, is still rarely studied beforehand.

2. This dissertation analyzes the influence of leadership participation, organizational culture, and innovation on organizational ability and cooperative performance, while many other factors that influence cooperative performance are still many that have not been revealed in this study.

3. The sincerity of the respondents when the research is conducted is things that are beyond the reach of researchers to control them. 
4. This study examines hypotheses carried out together, meaning that they do not group each respondent based on the characteristics of respondents such as: education level and work period, so it is not known whether there are differences in responses or evaluations of cooperative leaders towards research variables.

\section{BIBLIOGRAPHY}

Abdul Rosyid, and Imam Triarso ). 2013 Analysis of Makaryo Mino's Performance Of Village Cooperative Unit For Community Empowerment Fishermen In Pekalongan ( Analysis Performance KUD Makaryo Mino in Empowerment Business Society Fishermen in Pekalongan City ( Brefin Mushtaf Adam *),

Anwar Prabu Mangkunegara 2016 Management and Management Performance Source Power Human Company, Bandung: PT Remaja Rosdakarya

Alfred Chandler 2012 Strategic Planning and Firm Performance: A Synthesis of More Than Decades of Research. Academy of Management Journal Vol 37 No. 6.

Alfred Chandler 2012 Strategic Planning and Firm Performance: A Synthesis of More Than Decades of Research. Academy of Management Journal Vol 37 No. 6.

Albercht Chandler 2015 People and Organizational Culture; A Profile Comparison Approach to Assessment Person - Organization Fit, Academy of Management women Aini and Achmad Hendra Setiawan, 2006. Analisis Factors Affecting Participation Member Cooperative Serba Usaha (KSU) Save Business Unit Loan (USP) Employee City Regional Government Semarang .

Avanti Fontana, 2014, " The Effect of Organizational Culture Innovation and Business Strategy on Company Performance ", Proceedings of the National Seminar on Call for Paper, ISSN ISBN 978- 979-3649-65-8

Anoraga , Panji , 2013 , Dynamics Cooperative , PT Rineka Cipta, Jakarta. Wise Sugianto 2012 Performance Cooperative and Identification Factor - factor Main in Strengthening Cooperative Milk in Central Java .

Wise Sugianto 2012 Analysis Competence Managerial - Performance Cooperative and Identification Factor - factor Main in Strengthening Cooperative Milk in Central Java .

Arayesh , Bagher . 2011 Identifying the Factors Affecting the Participation of Agricultural Cooperatives' Members Brown and Petrello 2015 Human Resources Management, An Experiential Ap proach, Mc Graw -Hill. Inc. New York.

Davis and Newstrom 2014 Management of Organizations and Human Resources , USA: Wm. C. Brown Company Publisher.

Donald S. Metscher , 2005 An Examination of the Perceived Leadership Practices and Organizational Commitment of Active Duty Air Force Personnel and Government Civil Service Employees.

F Urbani Izziv , 2014 From Reaction To Initiative: Potentials of Contributive Participation Center , Aidan.

Hughes and Kapoor 2014 The Law of Partnership , Sydney, The Law Book Company Limited Glos , Steade and Lawry 2015 Management, Mc Graw Hill, Inc. San Francisco .

Hendar and Kusnadi , 2014 , Economics Cooperative For College High , Edition First, prints First, Publisher Institution Publishing UI FE, Jakarta.

Huat, T Chwee 2013 Minner, John B, 2008, Organizational Behavior Performance and Productivity , 1st Edition . Canada Toronto: Random House, Business Division.

Harvey, DF and DR Brown, 2009, An Experimental Approach to Organization Development, Prentice Hall International, New Jersey

Krisnamurthi , 201 2, Build Cooperative Based Member In Order Development People's Economy , Journal of People's Economy. Th. I No.4 June 2012.

Kaplan and Norton A Study of Relationships Between Construction Packages, Work Motivation and Jobs Satisfaction . Journal of Organizational Behavior.

Lucky Megalia Nornita . 2012 Analysis of Organizational Health Levels and Participation of Study Members on Cooperative Bina Ihsanul Fikri 2000 - 2011.

Linda O'Riordan and Jenny Fairbrass 2015 , Cooperative Management Performance, Rineke Cipta, Jakarta

Liliweri ( 2014 Koperasi Indonesia, CV Masagung Publisher , Jakarta. 
Audah, A. K., Ujianto., \& Kusmaningtyas, A. (2019). The Influence Of Participation Leadership, Organizational Culture, Innovation To Organizational Capability And Cooperative Performance In The Province Of South Kalimantan. Archives of Business Research, 7(3), $125-132$.

Lussier , Achua. (2013 , Behavior Organizations, Structure and Processes, Fifth Edition, Texas; Business Publication, Inc. 